\title{
Bourgeois Tensions, Marxist Economics and Aphaeresis of Communal Spirit in Sembene Ousmane's God's Bits of Wood and Ngugi wa Thiong'o's Devil on the Cross
}

\begin{abstract}
This article appraises the poetics of two of the foremost African creative writers whose literary sensibilities exhibit conspicuously Marxist conceptual models. The writers have poignantly deployed their creative ingenuities towards raising social consciousness against the bourgeois economy which imposes a politics of asymmetry, parasitism and stratification on the economic thought of the African society that once projected a communal spirit. Considering the precarious conditions of Africa's economy due to the pernicious effects of capitalism, it is imperative to examine the sordidness of classism, alienated labour, commodification or thingification of the underclass and other bourgeois tensions in African literature, as portrayed by these writers. Marxist theoretical models of economic determinism and historical materialism are discussed as the simulacrum of Vilfredo Pareto's 80/20 Rule or Pareto Principle. Though Marxists are fixated on revolution as the only solution to end the misery of the underclass and terminate the hegemony of the oligarchy that exploits sellers of labour, the paper advocates economic revivalism through the exploration of the opportunities offered by the communal mode of production.
\end{abstract}

Keywords: Marxism; Sembene Ousmane; Ngugi wa Thiong'o; capitalism; African literature; communalism

\section{Buržoazne napetosti, marksistična ekonomija in afereza kolektivnega duha v God's Bits of Wood Sembeneja Ousmaneja in Devil on the Cross Ngugi wa Thiong'oa}

\section{POVZETEK}

Članek obravnava poetiki dveh vodilnih afriških piscev, katerih literarna senzibilnost izkazuje očitne marksistične konceptualne modele. Pisca svoje ustvarjalne sposobnosti usmerjata v oblikovanje družbene zavesti, naperjene proti buržoazni ekonomiji, ki je v ekonomsko misel afriške družbe, za katero je bil nekoč značilen kolektivni duh, nasilno vnesla politiko asimetrije, zajedavstva in razslojenosti. Z vidika negotovosti, ki so jo v afriški ekonomiji povzročili škodljivi učinki kapitalizma, je v okviru književnosti nujno izpostaviti pokvarjenost razredne razslojenosti, odtujenega dela, komodifikacije in stvarifikacije najnižjega razreda ter drugih buržoaznih napetosti. Marksistični teoretski modeli ekonomskega determinizma in historičnega materializma so obravnavani kot simulaker Paretovega načela 80/20. Čeprav marksisti izpostavljajo revolucijo kot edini način za odpravo trpljenja in revščine najnižjih razredov ter uničenje nadvlade oligarhije, ki izkorišča delavce, se v članku zavzemam za oživitev nekdanjih ekonomskih praks in raziskujem možnosti, ki jih ponuja skupnostni model proizvodnje.

Ključne besede: marksizem; Sembene Ousmane; Ngugi wa Thiong’o; kapitalizem; afriška književnost; komunalizem 


\section{Bourgeois Tensions, Marxist Economics and Aphaeresis of Communal Spirit in Sembene Ousmane's God's Bits of Wood and Ngugi wa Thiong'o's Devil on the Cross}

\section{Introduction: Poetics of Marxist/Socialist Realist Writers}

Sembene Ousmane's God's Bits of Wood (Les bouts de bois de Dieu) and Ngugi wa Thiong'o's Devil on the Cross can be described as blueprints for social transformation and enthronement of classlessness in Africa through a series of planned revolutionary actions (Ikiddeh 1985, 47). The texts are the chef doeuvre and creative contributions of the writers to polemics on class struggle, bourgeoisieproletariat oppositionality as well as the knotty issues of inequality and poverty. Through the texts, Sembene and Ngugi explore the appropriateness or otherwise of an economic system suitable for African socioeconomic space and exploitation of the poor by the unscrupulous oligarchy. The novels reify some conceptual models of Marxism to interrogate the moral philosophy underpinning bourgeois or laissez-faire economics in a sociocultural space that frowns at individualism, because its indigenous economics is largely communal-driven. This article, therefore, considers the parlous state of Africa's economy and connects its precariousness to the pernicious effects of capitalism. It examines the sordidness of classism, alienated labour, commodification of the underclass and other bourgeois tensions as portrayed by both Sembene and Ngugi. Marxist theoretical models of economic determinism and historical materialism are discussed as the simulacrum of Vilfredo Pareto's 80/20 Rule or Pareto Principle, just as the article advocates economic revivalism as a possible panacea to bourgeois tensions foisted on the African economic logic.

Since Marxism is a sociological critical theory (Onoge 2007, 471; Ogundokun 2014, 74) that negotiates the material/historical relationships among people living in society, ${ }^{1}$ the tone and mood of the texts are tense and swing in favour of the oppressed masses in their bid to win the economic power needed for the control of means of production (Ngugi 2007, 481). Through their poetics, Sembene and Ngugi have often evinced anti-bourgeois sentiments, and it may be apposite to regard the duo as combative elements and the "vanguard [of] the revolutionary efforts [for] a better society" (Olaniyan and Quayson 2007, 461) $)^{2}$. They actualise these revolutionary agenda through their poetics, which is a form of social action for whipping up the feeling of the impoverished in Africa against the "combined forces of bourgeois establishment" (Adebayo 1985, 58). Considering a number of tropes, imageries, signs, symbols, and metaphors that run through their texts, both Sembene and Ngugi can be said to have engaged in intertextual dialogism or dialogic intertextuality. ${ }^{3}$

Marxism operates through the complex process of the socioeconomic base and related cultural, intellectual, legal, spiritual, or ideological superstructures (Tyson 1999). Being "a social, political and economic philosophy that examines the effect of capitalism on labor, or productivity and economic development," Marxism gives prominence to the struggle between social classes, because of the belief that the struggle between social classes "defines the development of the state, and the bourgeoisie seek to gain control of factors of production from the 'masses' ... [and] only by eliminating the control of the economy from private ownership will the economy continue to grow." See also www.investopedia.com/terms $/ \mathrm{m} / \mathrm{marxism}$.

A quote from Tejuomola Olaniyan and Ato Quayson's editorial comment on Marxism in their volume: African Literature: An Anthology of Criticism and Theory (2007, 461).

An attempt is made here to combine Mikhail Bakhtin's and Julia Kristeva's terms of dialogism and intertextuality, 
As Marxist writers who deploy their creativities to "reflect social reality or certain aspects of social reality" (Ngugi 2007, 478) within the African cultural milieu, their poetics clearly reflect their partisanship. Their prejudice is possibly a corollary of their sentiments against the trajectories of the capitalist mode of production in Africa and the attendant rupture or damage that this economic system has caused to the African communal spirit. Besides, the intensity of their concern for the proletariat presents them as tribunes of the underclass and oppressed masses. This thus indicates that the writers may demonstrate Marxist sensibilities in their works.

To lend credence to the foregoing statement, Ngugi (2007) provides what may be regarded as the credo of a socialist realist/Marxist writer - to defend the oppressed against destructive and organised capitalist structures engendered to ensure their alienation. Since capitalism embodies inhumanity and lacks redeeming features (Adebayo 1985, 59), it is imperative for African writers to "join the proletarian and the poor peasant struggles against the parasitism of the comprador bourgeois, the landlords and the chiefs, the big business African classes that at the same time act in unison and concert with foreign interests" (Ngugi 2007, 481). A socialist realist or Marxist writer, Ngugi (2007, 481-82) further posits, must:

recognize the global character of imperialism and the global character and dimension of the forces struggling against it to build a new world. He must reject, repudiate, and negate his roots in the native bourgeoisie and its spokesmen, and find his true creative links with the pan-African masses over the earth in alliance with all the socialistic forces of the world ... He must write with all the vibrations and tremors of the struggles of all the working people in Africa ... He must actively support and in his writing reflect the struggle of the African working class and its class allies for the total liberation of their labour power. Yes, his work must show commitment, not to abstract notions of justice and peace, but the actual struggle of the African peoples to seize power and hence be in a position to control all the forces of production to lay the only correct basis for real peace and real justice.

Sembene's and Ngugi's principles for socialist realist literature and writers are dominant in both God's Bits of Woods and Devil on the Cross. The texts present an interplay of actions and counteractions, as well as events or happenings that validate the Marxian/Engelsian materialist philosophy in Communist Manifesto. ${ }^{4}$ The materialist philosophical thought reiterates the hypothesis that the history of all hitherto existing societies is one of class struggles between the Manichean duality of freeman and slave, patrician and plebeian, lord and serf, guild-master and journeyman, oppressor and oppressed, progressives and reactionaries, tyrant and liberator, darkness and light ${ }^{5}$ who are often in "constant opposition to one another ... [and] a fight that ... [may end up in] either ... a revolutionary reconstitution of society at large, or in the common ruin of the contending classes."

respectively. Some scholars believe that the terms can also be used interchangeably, while some believe that dialogism can also mean auto-textual or intra-textual dialogue, while intertextuality refers solely to dialogue between a text and its precursors.

4 The version of Manifesto of the Communist Party consulted is Marx/Engels Selected Works (Moscow: Progress Publishers, 1969, Vol. 1:98-137, translated by Samuel Moore).

5 This is a quote from the Manifesto of the Communist Party, otherwise known as the Communist Manifesto. The phrases: "progressives and reactionaries", "tyrant and liberator" and "darkness and light" are not part of the quote. I included them to elaborate on the binary oppositional forces struggling against each other in Marxist dialectics.

6 Ibid. 


\section{Towards the Creation of Marxist/Socialist African Society}

Sembene's text reveals the interpolation of Marxist historical materialism in colonial Senegal, while Ngugi's text spotlights the evils of class struggle in post-independent Kenya. Since the aim of Marxism is to engender a classless society, whereby ownership of means of production, distribution and exchange is vested in the community and not in the hands of private individuals (Barry 1995), it is understandable why the writers are fixated on creating a Utopian socialist African society that will tackle the questions of inequity, inequality and corruption. With the aim of achieving this surreal mission, literature is used as a necessary tool and opportunity to idealise and build a Utopian African society based on the foundation of Marxist dialectics.

The praxis of Marxism underscores the belief that social consciousness in a society is often determined by the nature of its economic basis, and that no social reality is left uninfluenced by this. This is called economic determinism in Marxist discourse (Barry 1995, 158). As such, Karl Marx believes that the chief determinants of a society and its institutions are basically economic factors (Guralnik 1979, 665). Historical materialism, on the other hand, is the reification of the belief in Marxism that the most important determinants of society and its institutions are economic in nature, while dialectical materialism refers to the observable social and economic processes that an idea or event (thesis) generates its opposite (antithesis), leading to a reconciliation of opposites (synthesis) (Guralnik 1979, 665). The antithesis as portrayed in God's Bits of Wood is the resolution of an anti-bourgeois-capitalist system to revolt against an oligarchic regime that expropriates the sweat of the poor. The bourgeois establishment nurtures a warped socio-economic philosophy where 10 or 20 per cent of the population in colonial Senegal (property owners or bourgeoisie) has access to and enjoys the wealth produced by 90 or 80 per cent of the population - the working class in the Francophone country. This is a simulacrum of the Pareto Principle in Marxist dialectics.

The Pareto Principle - like Marxist dispositions against oppression, injustice and inhumanity comments on, but not necessarily condemns, inequality, inequity and exploitation of the poor by those who control the means of production, distribution and exchange in a society. The nexus between this concept and Marxism is signified by the evils of expropriation, social injustice, and oppression or suppression of the working class. The Pareto Principle, like Marxism, calls attention to the plight of the underclass whose labour is expropriated by an unconscionable oligarchy. Capitalism is thus erected on a foundation of injustice or criminality. Its coercive structures (the police, army, and other security apparatuses) and its non-coercive ideological agencies of school, religion, patriotism, and consumerism (Tyson 1999) work surreptitiously to chain or imprison the consciousness of the oppressed working class, hence the dogged determination of the oppressed to end their misery and create a Utopian society.

The Pareto Principle, or 80/20 Rule, emphasises the level of asymmetry in a society, organisation or other areas of human existence. It was propounded by Vilfredo Pareto (1848-1923) after his realisation that 80 per cent of wealth in his country, Italy, was owned by 20 per cent of the people. The theory helps to validate the Marxist concern about inequitable production, distribution and exchange of wealth among people in a capitalist milieu, and the fact that the bourgeoisie, due to their unfettered access to the means of production and possession of stupendous wealth, often exploit the proletariat. This theory has also been applied to topics in management studies, engineering, mathematical science, economics, and so on. For more on the Pareto Principle, see https:// en.wikipedia.org/wiki/Pareto_principle. 


\subsection{Marxist Reading of God's Bits of Wood}

A Marxist hermeneutics of Sembene's God's Bits of Wood brings to the fore the age-long social conflicts that often shape any society torn apart by class struggle and inequality. As portrayed in the novel, social conflict in Senegal pitches two diametrically opposed groups against each other in a bid to negotiate better economic conditions for the "exploited sellers of labour" (Ikiddeh $1985,47)$, that is the working class, against the economic interests of the bourgeois establishment. Sembene historicises the social conflict brought about by the 1947-48 workers' strike on the Dakar-Niger railway line, and the economic determinist conditions that necessitated industrial action. Ibrahim Bakayoko, a hard-headed activist who symbolises self-sacrificing leadership in the narrative, embarks on the mission of economic liberation and restoration of the dignity of the working class. The workers, who mainly depend on railway work as their only source of income, have gone on strike to demand a pay rise and better conditions. Dejean, the regional director of the railway company, scornfully states the workers' demands as: "A raise in the pay scale, four thousand auxiliary workmen, family allowances, and a pension plan!" (Sembene 1960, 29). The workers' demands are not in any way political but economic. This captures the thrust of economic determinism and historical materialism. To corroborate the foregoing, Bakayoko tells Dejean not to see their struggle as a politically motivated one, but a class struggle necessitated by economic considerations: "We know what France represents ... and we respect it. We are in no sense anti-French; but once again, Monsieur le directeur, this is not a question of France or her people. It is a question of employees and their employer" (Sembene 1960, 184-85).

In her comment on the thematic thrust of Sembene's text, Adebayo (1985) states that the desire to restore the dignity of workers, improve their living conditions, and end their misery is immanent in Sembene's creative productions. All Marxist creative writers or socialist realist authors share this passion, as they highlight in their works the desire for proletarian or social revolution and the conflicts birthed by "economic rather than racial or political" $(1985,58)$ motives. She believes that the conflict between the opposing forces in the text is occasioned by the "tension ... between labour and capital, between the forces of progress and those of reaction" $(1985,62)$. The struggle, however, results in the loss of lives - a loss which, nevertheless, is seen as the inevitable price to be paid for the emancipation of the working class. Characters such as Penda, Houdia Mbaye, Doudou, Samba N'doulogou, Niakoro and others lose their lives in the process. The workers, through their doggedness, overcome the hardship unleashed on them by the management of the railway company. They discover that the massing together of individuals against industrial capitalism is a prerequisite for their own emancipation (Adebayo 1985, 62). Sembene perhaps expresses this motif better in his poem "Fingers," where he calls for a mass action against the bourgeoisie who neither toil nor spin but control the "wealth of nations":

Fingers, skillful at sculpture

At modeling figures on marble

At translation of thoughts

Fingers of artists.

Fingers, thick and heavy

That dig and plough the soil

And open it up for sowing.

And move us. 
Fingers of land tillers.

A finger holding a trigger

An eye intent on a target finger

Men at the very brink

Of their lives, at the mercy of their finger

The finger that destroys life

The finger of a soldier

Across the rivers and languages

Of Europe and Asia

Of China and Africa

Of India and the Oceans.

Let us join our fingers to take away

All the power of their finger

Which keeps humanity in mourning ${ }^{8}$

Sembene's poem includes two different fingers: that of the rich and that of the poor, the oppressor and oppressed, haves and have-nots. The synecdochic tensions that dominate the poem account for the representation of human life with fingers. The lexeme, finger, evokes imageries of work, toil, labour and oppression. Consequently, some fingers only "dig and plough the soil," plant and exist at the mercy of other fingers. Some fingers only exploit other fingers and unleash a reign of terror on them. Sembene, through the poem, exposes the evil of capitalism and its oppressive structures against the working class. To him, the only way to break down capitalist structures lies in the hands of the oppressed people who need to unite and join their efforts (fingers) to combat the combined forces of the bourgeois establishment.

Suffice it to say that this poem shares some intertextuality with a work of the Romantic poet Percy Bysshe Shelley. Entitled "Song to the Men of England," the poem catalogues the asymmetric and parasitic relations between the owners of the means of production and the working class. Rather than having an equitable distribution of wealth and resources, the oligarchic bourgeoisie treat societal wealth as their exclusive preserve. They also use such resources to further impoverish the masses who, in a very real sense, generate the wealth. This disparity and the lord-serf relationship are shown by Shelley as the pitiable fate of the working class. The poet calls the bourgeoisie tyrants, ungrateful drones and bees. He sounds a clarion call to the oppressed masses to come to full awareness of what Ikiddeh $(1985,38)$ calls the condition of "sub-human imbecility and viciousness" to which the bourgeois economy has relegated them. Shelley writes:

Men of England, wherefore plough

For the lords who lay ye low?

Wherefore weave with toil and care

The rich robes your tyrants wear?

\footnotetext{
"Fingers" is contained in Ngugi's "Writers in Politics: The Power of Words and the Words of Power," African Literature: An Anthology of Criticism and Theory $(2007,482)$.
} 
The seed ye sow, another reaps;

The wealth ye find, another keeps;

The robes ye weave, another wears;

The arms ye forge, another bears. ${ }^{9}$

The imagery of fingers in Sembene's poem and Shelley's metaphor, ungrateful drones, are correlates. Both typify the privileged few who do nothing, like drones (male bees) in a bee colony, but oppress the poor. Like drones who manipulate queens and worker bees the bourgeoisie hegemonise the proletariat with a view to exploiting them. The tropes of alienation and revolution that pervade Shelley's poem are also noticeable in Sembene's God's Bits of Wood, as well as his other works, such as Le Docker Noir (1956), O Pays Mon Beau Peuple (1957) and his films. The tropes reflect social disorderliness and a call for proletarian revolution or violent uprising against the oppressors of the underclass. By telling the oppressed to "Sow seed, - but let no tyrant reap;/Find wealth, - let no imposter heap:/Weave robes, - let not the idle wear:/Forge arms, - in your defence to bear" (Miller and Greenberg 1981, 269), the persona in Shelley's poem projects a Marxist spirit. To "forge arms" and defend one's rights is a euphemism employed by the persona to ignite the proletarians against their taskmasters. The Marxist temper in the text thus underlies the workers' stand against the bourgeois establishment, hence their desire for social revolution and passion to overthrow the status quo. Another revelation brought about by the Marxist reading of the novel is the repressive structure which the management of the railway company fosters on its striking workers. Peter Barry $(1995,164)$, while explaining the Althusserian terms "Repressive structures and ideological structures or [s] tate ideological apparatuses," notes that they are:

institutions like the law courts, prisons, the police force, and the army, which operate ... by external force ... groupings as political parties, schools, the media, churches, the family, and art ... which foster an ideology - a set of ideas and attitudes - which is sympathetic to the aims of the state and the political status quo.

This conceptual model is evident in the killings and arrests of some leaders of the strike committee. Fa Keita (the Old One) and Konate as well as other striking workers are unlawfully arrested and maltreated in prison by Bernadini. Sembene $(1960,236)$ paints a grotesque picture of Bernadini's brutality as a symbol of colonial repressive force against the striking workers:

as Fa Ke'ita began to kneel, the 'commandant's' boot caught him in the kidney and hurled him head first into the strands of barbed wire. Little drops of blood flecked the skin of the old man's shoulders and back and sides.

The ideological apparatuses ${ }^{10}$ used by the state to quell uprising and silence the oppressed are indicated in the texts. Through the characterisation of Imam, who is pejoratively regarded as the spiritual guide of the oppressor, futile attempts are made to muffle dissenting voices. Gaye, El Hadji Mabigue and their ilk also use similar tactics to discourage the striking workers from pursuing their struggle. The Imam uses his religious sermons to discourage the workers. He

Shelley's "Song to the Men of England" is from the anthology Poetry: An Introduction (Miller and Greenberg 1981, 268-69).

10 This term is credited to Louis Althusser, a French Marxist. State ideological apparatuses are structures that the state uses to oppress the underclass and muffle the voices of opposition. Peter Barry $(1995,164)$ identifies the apparatuses as including "... political parties, schools, the media, churches, the family, and art (including literature) which foster an ideology ... sympathetic to the aims of the state and the political status quo". 
tells them that their leaders are evil and that the French government has been magnanimous to them, hence the need for the workers to end their protests. Marxist dialectic materialism, in which social and economic processes are observed based on the theories of thesis, antithesis and synthesis, is evident in the narrative. Thesis is often conceived as a proposition or action advanced to support a view or perspective, while antithesis presents a counter view or action. Synthesis is a fusion or syzygy of the opposite positions. The thesis of the narrative is the resolve of railway workers to down tools in order to demand a pay rise, while the narrative's antithesis is generated through the variety of subtle or violent means employed by the management of the railway company to break the dissidents and their collective will. The synthesis of the narrative is signposted by the syzygy of pro- and anti-workers' demands and the eventual acceptance of key demands of the workers by the management. This signals the victory of collective solidarity over selfish arrogation of wealth by the bourgeoisie and a possible justification of the view that the goal of Marxism is not to breed dissidents or die-hard revolutionaries. Instead, Marxism seeks to create a just and egalitarian society where proletarians do not exist at the mercy of the bourgeoisie.

\subsection{The Image of Woman as Tribune of the Oppressed}

Of importance to the victory recorded over the oligarchic bourgeoisie is the invaluable contribution of women in the text. Without them, the strike would have been quelled without any positive outcome. The first man to heed the call for strike says: "We are not ashamed to admit that it is the women who are supporting us now" (Sembene 1960, 73). Beyond providing active support and serving as the intellectual force driving the strike, women in the novel, as symbolised by Dieynaba, Maimuna, Mame Sofi, Houdia M'Baye, Ramatoulaye and Penda, break the patriarchal barriers and sexist ordering of African society to become leaders and revolutionary voices. It should be noted, though, that Adebayo $(1985,69)$ believes otherwise, stating that "Characters are never perceived in terms of their sex in [Sembene's] novels. Like the men, his women are either progressive or reactionary." However, the roles of female characters in the text and his other creative productions should not be given a loose or superficial hermeneutics. Their actions typify an exchange or a swap of roles between the sexes, in such a way that women assume the position of a provider while men are at the receiving end of their actions. Mame Sofi's dialogue with N'Deye Touti on the role of men in the struggle against their colonial oppressors and men's vaunted claim of superiority over women is revealing. She tells N'Deye Touti: "You'll see - the men will consult us before they go on another strike. Before this, they thought they owned the earth just because they fed us, and now it is the women who are feeding them" (Sembene 1960, 48). Sembene thus expounds Marxist-feminist ideology where women negotiate freedom from the inhibiting forces stymieing the actualisation of their dreams and aspirations.

Sembene - as a rebel-revolutionary and so-called Father of Cinema in Africa - fixates on the image of female-character as a protagonist in most of his works (filmic and non-filmic) to champion the rights of the oppressed. As female characters dominate his textual narratives, they also do in some of the films produced by this self-made literary icon who said in a documentary, Sembene Across Africa, ${ }^{11}$ that he took to literature in order to "give voice to the voiceless" and challenge the warped Eurocentric conception of Africa as a "moribund" and underdeveloped milieu of ${ }_{11}$ The documentary was produced by Samba Gadjigo and shown at the Institute of African Studies, University of
Ibadan, Nigeria, on 9th June 2017, as well as in some African countries at around the same time. 
sub-humans. The documentary contains snippets of films made by Sembene with conspicuous dominant female protagonists. In La Noire de (Black Girl 1966), for instance, the protagonist, Diouana, is lured into child labour by a French couple who hire her as a maid in Senegal and take her to France to do home chores "[w]ithout salary or friends, [but] treated as invisible by her employers, confined to the house except for shopping” (Landy 1982). Diouana eventually commits suicide to protest against her dehumanised condition and disillusionment. The film dramatises how those who control the means of production exploit the vulnerability, ignorance, innocence and illiteracy of the poor to reap the benefits of their labour. With Diouana's suicide, however, the heroine buried in her personality is unmasked, and Sembene draws attention to her strength of character. She refuses to be cowed by the capitalist system typified by her bourgeois French mistress. Despite her death, she symbolises freedom, resistance and victory over the inhuman bourgeois social system. Diouana's death attacks the materialist foundation of capitalism and exploitation of the poor. This image of a woman as a leader, a tribune of the voiceless or an activist also features prominently in Sembene's filmic productions, such as Mandabi (1969), Emitai (1972), Xala (1974) and Ceddo (1977).

\section{Impoverishment of Proletarians through Mercantilism}

In Ngugi wa Thiong'o's Devil on the Cross, the post-independent Kenyan society is displayed for clinical scrutiny. The work presents binary opposites as forces that engage in a struggle for socioeconomic gain and supremacy. These social forces include the haves and the have-nots, centre and margin, core and periphery, oppressor and oppressed, bourgeoisie and proletariat. Commenting on the forces at work in the text, and, by extension, in post-colonial Kenya, Muturi notes that:

the force of the clan of producers, (and) forces of destruction, of dismantling, of harassing and oppression, the builders and the creators, the forces that seek to suppress our humanity turning us into beasts in order that we should create our own Hell, thus taking on the nature of Satan - these are the forces of the clan of parasites. (Ngugi 2002, 54)

Ngugi uses the novel to call on Kenyan proletarians - and all the abjected people of Africa who live in drudgery - to rise against their oppressors. The oppressors promised a prosperous, egalitarian post-independent Kenya for all during the struggle for independence, but turned the tables against the cannon fodder who helped in actualising freedom from Britain for the East African country. The Kenyan masses are thus exploited by their countrymen who proudly regard themselves as local thieves and robbers, comprising capitalists such as Gitutu wa Gataanguru, Kihaahu wa Gatheeca, Mwireri wa Mukiraai, Nditika wa Nguunji and other corrupt Kenyan business owners. They converge on Ilmorog to attend the Devil's Feast organised by the Organisation for Modern Theft and Robbery. Their testimonies reveal how unscrupulous individuals, through carefully designed capitalist ideologies, exploit peasants without the conscious awareness of the oppressed.

In the text, Mwireri wa Mukiraai calls for the indigenisation of theft and robbery. In other words, Mukiraai advocates the endorsement of mercantilism - a type of capitalism, which, according to Landreth and Colander $(2002,45)$, operates on the basis that the best way to increase the wealth of the nation is by "encouraging production, increasing exports and holding down domestic consumption” (Rankin 2011). Mukiraai has a cognate understanding of the change he advocates. He knows that mercantilism operates on the logic of inequality and impoverishment of the 
working class. In fact, mercantilism is sometimes called a "beggar-thy-neighbour" or "beggarthy-competitor" (Steil 1994, 14; Rankin 2011, 2) economic system.

Landreth and Colander (2002) elaborate further on the features of mercantilism. To them, this economic philosophy increases the wealth of a privileged few through the poverty of many. It operates on a warped economic logic that supports payment of low wages to workers (Landreth and Colander 2002), thereby deepening their impoverishment. Mercantilists believe that "wages above a subsistence level would result in a reduced labor effort ... higher wages would cause laborers to work fewer hours per year, and national output would fall" $(2002,45)$. With the foregoing scenario, Kenya and the proletarians in the Devil on the Cross are in the grip of the worst set of bourgeoisie practices, hence the metaphor of the Devil that the text often returns to. Ngugi must have chosen it to foreground the atavistic instinct of those who boastfully call themselves robbers and thieves of the people's labour. Mukiraai undoubtedly speaks the minds of other local capitalists when he intones:

I ... believe only in the first kind of theft and robbery: that is, the theft and robbery of nationals of a given country who steal from their own people and consume the plunder right there, in the country itself ... (Ngugi 2007, 166)

Althusserian interpellation better captures the mind-set of Mukiraai and his ilk in the novel. The concept, according to Barry $(1995,165)$, is a web of tricks spun by capitalists to pull the wool over the eyes of proletarians who they (the bourgeoisie) make believe are "free and independent of social forces" that hinder their upward socioeconomic mobility. In Ngugi's narrative, it takes the intervention of Gatuiria and Jacinta Waringa to expose the precarious state of the exploited in Kenya. Symbolically, Ngugi seems to say that the exploitation or economic deprivation of the underclass will persist unless social critics rise up to the challenge. This is because the economic strangulation of Kenyan peasants by local capitalists operates through some insidious ideological principles. These are woven into a tapestry of lies and propaganda and operate through a set of belief systems that keep the oppressed ignorant of the operation of the socioeconomic forces that work against them. The economic deprivation of the working class, as reflected in the mercantilist goals of low wages, reduced domestic consumption, inflation, scarcity, hoarding of essentials and high unemployment, enables the oppressors to muffle the voices of opposition. Boss Kihara, for instance, fires Jacinta Waringa for refusing to sleep with him. Muturi is jobless for a long time, and is eventually arrested, while looking for work, for being unemployed! Githai impregnates Waringa, using money as a tool to deceive her. These events underscore the economic trajectories that influence the larger superstructure in the text.

The fate of Waringa and Muturi is built on the base structure of economic privations that keep them alienated or abjected. Rather than operating an economic system that ensures equity, the economics in Devil on the Cross are one-sided, as they only favour the local bourgeoisie in Kenya to the detriment of the less-privileged. In Marxist dialectics, therefore, Kihara commodifies or thingifies $^{12}$ Waringa. He relates to Waringa the way he would relate to "objects or persons in terms of their exchange value or sign-exchange value" (Tyson 1999, 59). In his Marxist reading

12 Thingify is the verb form of thingification - a term coined by Aimé Césaire in his seminal work, Discourse on Colonialism (Discours sur le colonialism) $(1972,6)$. He notes that "colonization = 'thing-ification", because colonisation imposes "relations of domination and submission" on the "colonizing man" and turns him "into a class-room monitor, an army sergeant, a prison guard, a slave driver, and the indigenous man into an instrument of production." 
of F. Scott Fitzgerald's The Great Gatsby, Lois Tyson $(1999,69)$ offers a clear interpretation of commodification through the character of Tom, noting that:

Tom's commodification of people is his ability to manipulate them very cold-bloodedly to get what he wants, for commodification is, by definition, the treatment of objects and people as commodities, as things whose only importance lies in their benefit to ourselves.

Ngugi uses the novel to show how social revolution can be used as a weapon to change the socioeconomic status quo. A long procession of women, men and children in Njeruca, for instance, is organised by Muturi and a student leader. The procession moves to the cave where a meeting is on-going, chasing away the thieves. Though five of the protesters die, they succeed in upturning the symbol of oppression and capitalism. Waringa also kills Githai, the father of her fiancée, Gatuiria. She shoots Kihaahu and Gitutu too, thus signalling how the force of clan of workers can subdue and triumph over that of destroyers. The conflict in Devil on the Cross is also both social and economic. It is a struggle that pitches workers against their employers. It is a struggle to gain access to the control and management of the means of production, distribution and exchange in order to ensure the economic wellbeing and enhance the social statuses of people belonging to either the bourgeoisie or proletariat.

The repressive structures theorised by Louis Althusser are fully employed against the opposing voices in the text. Senior Superintendent Gakono orders his boys to arrest Wangari who has often deluded herself that she will assist the law enforcement agents in clearing Kenya of thieves and hoodlums. She asks when ordered to be arrested: "So you, the police forces, are the servants of one class only?" (Ngugi 2007, 198). Tyson (1999) shares Wangari's concern as to how the state apparatuses are used to suppress opposing voices. He believes that "Other elements oppressing [the poor] are the police and other government strong-arm agencies, who, under government orders, have mistreated lower-class and underclass poor perceived as a threat to the power structure" $(1999,52)$.

\subsection{The Hunter and the Hunted Game}

The "hunter and the hunted" game played by the Old Man of Nakuru is also symbolic of oppositional forces that serve as correlates of Marxist bourgeois-proletariat divides. Githai often carries a loaded gun and pursues Waringa in the bush as though she were a game bird. Waringa sometimes acts as the hunter while Githai acts as the hunted. The game is a metaphor for oppositional relationship between the haves and have-nots. To ensure the continued existence of capitalism and its implicit ideologies or structures, the proletariat have to be kept in check to ensure that they do not upset the system. They seem to say that the best way to keep the working class down is to make them poor or create inhibiting structures around them that can deepen or perpetuate their impoverished status. Moreover, since the poor will want to change the status quo, the stage is set for mutual hostility and struggle. Waringa acting as a hunter is a metaphor of role reversion with regard to the bourgeoisie and proletariat in reality. The reversion possibly fulfils the personal unconscious of Ngugi in addressing the inequity and inequality that pervades the entirety of Kenyan society. In fact, Waringa nearly shatters the head of Githai on one occasion when she mistakenly pulls the trigger of the rifle in her hands. With the foregoing, Ngugi seems to foreground the collective unconscious of the poor and the desire to end their misery through armed struggle against their oppressors. It symbolically portrays the agitated condition of the proletariat in Kenya who will one day turn the tables and eventually hunt the hunted! 


\subsection{Ujaama Socialist Philosophy and African Society}

What Ngugi advocates in the text is a classless society. Capitalism glorifies classism; it further uses it as an ideology to insidiously chain the minds of the oppressed by "colonizing [their] consciousness" (Tyson 1999, 60). Doing this will constantly remind them of their underclass status and etch on their consciousness their mental, spiritual and cultural inferiority (Tyson 1999, 60). To Ngugi, a society that fails to mutualise love and respect, and thus put humanity at its centre, is a warped one. Such a community is oiled by the lubricant of capitalism that is imbued with a "bourgeois passion ... [and] bourgeois egoism" (Dada 1985, 31). To rectify this, Ngugi craves for a society where no one oppresses another, a class-free society where the means of production, distribution and exchange are not concentrated in the hands of private individuals, but controlled by the state for the benefit of all. This he calls Ujamaa wa Mwafrica. Ngugi thus envisions a home-grown African socialism that seeks "to recapture and modernize the communal way of life practiced by the traditional African before the exposure to the world and values of the white man" (Alofun 2014, 69). His socialism is a domesticated version of European socialism/ communism or an African-based socialist philosophy that leverages the traditional communal spirit and consciousness of Africans, where everyone is seen in the light of John Mbiti's (1970, 141) canonical statement: "I am because we are and, since we are, therefore I am". His Ujamaa wa Mwafrica forecloses a society ridden with greed, corruption, consumerism, classism, inequality and other capitalist tensions. It embraces the African communal spirit, and preaches oneness as well as love instead of the divisions or struggles that attend capitalism.

\subsection{Erosion of Communal Consciousness in Africa}

The fight for the enthronement of egalitarianism and better economic conditions for the masses in Senegal and Kenya, as portrayed in the texts analysed in this work, is basically to restore or revive the lost communal consciousness of Africans. Capitalism thrives on the aphaeresis or erosion of communal spirit that once defined different African cultural groups. It pushes for selfindependence against the foundation of the umbilical, interdependent relationships on which communalism operates in Africa. Sembene and Ngugi want the dethronement of the status quo, hence their bias in favour of revolution of the working class as a counter against the oppression of capitalists. However, the latent content of the texts is not just about revolution, it is probably a lamentation over the loss of Africans' communal feelings, and the immorality of the ill-gotten wealth of the oligarchic bourgeoisie. Current events on the continent perhaps corroborate all this, since just an insignificant number of wealthy folk control the vast resources of Africa, leaving millions in the underclass in penury and misery. Mbiti's (1970) maxim, therefore, has lost its relevance, as many people on the continent have embraced the individualistic, self-centring or independent lifestyle of the West. This is the dilemma for Africa and its population. The writers signify this dilemma and project its cataclysmic effects on the social and economic fabric of African societies. To perhaps prevent total loss of communal spirit, the writers seem to suggest the need to go back to the old order that guarantees equality and prevents exploitation of the many by the few.

It is important to note that both Ousmane Sembene and Ngugi wa Thiong'o engage in intertextual discourse in their texts, considering the socialist realist mode or literary tradition that the texts belong to and the distillation of Marxist tropes and tensions in them. The two texts contain scenes of mass revolt and procession of the oppressed against the forces that suppress them. The powerful message of mass revolt is perhaps based on the potency of organised struggle 
and power of collectivism. Sembene, similarly, expounds this motif in his poem, "Fingers," while Ngugi has indicated this belief in both his creative and non-creative texts. To Marxist or socialist realist writers, mass struggle is the fuel that fires the engine of resistance and revolution. As a weapon used solely by women in God's Bits of Wood and by both sexes in Devil on the Cross, the efficacy of this approach with regard to engendering social transformation is astounding. Sembene Ousmane and Ngugi wa Thiong'o deploy their creative imaginations to sensitise the oppressed in the locales of the narratives and, by extension, the whole of Africa, to the power inherent in revolution. Shelley, in his poem, "Song to the Men of England," also employs this revolutionary technique to call on the oppressed to reject their inhuman treatment.

Marxist or socialist realist writers are likely echoing Sir Isaac Newton's First Law of Motion that a "stationery object will remain stationery unless and until it is acted on by a force or forces" (Farrow 1999, 164). In order words, freedom is fought for and won through the concerted efforts of the oppressed, not given on a gold plate. The misery of the poor will persist, and even increase, unless the force of revolution is applied. Revolution is the only language that the oppressors and thieves of people's wealth understand. Should the oppressed remain complacent like the "Men of England" during the English Romantic epoch, their oppressors, the ungrateful drones or tyrants, will ride roughshod over them. Not only that, they will bleed them dry till the value of their labour drops to nothing. (Violent) revolution is the sine qua non for the oppressed people of Africa to take up the reins of economic and political power. It is the only weapon they are left with in the face of orchestrated violence and wanton exploitation of their labour and resources. Sembene and Ngugi are conscious of this fact, and thus demonstrate it in their texts and prove that they are uncompromising spokesmen and consciences of the proletariat, with a mandate to unfetter the shackles that tie down the consciousness of the oppressed masses. Their texts, without a doubt, serve as a domain for championing social struggle and revolution.

\section{Conclusion}

Socialist realist literature, with its Marxist orientation or influences, has often created platforms where two opposing forces are brought into contact to enact or re-enact their mutual hostility. The resultant effect is very often that of revolution and social transformation, in which the oppressed overturn the status quo to their advantage. However, this is not always the case, since the bourgeois establishment may use the resources at its disposal to quell any opposition or uprising against its economic interests. Ultimately, the two texts appraised in this essay are quintessentially Marxist in nature, and belong to the literary convention of socialist realism. Apart from having Marxist conceptual models diffused in them, they also offer revolution as a solution to societal problems. The texts have shown how mass solidarity can be used to engender social revolution. The novelists deployed their creative ingenuities to resist oppression, inequality, poverty and other denigrating structures that are used for the exploitation of the masses. Their characters are enormously resourceful, passionate and intuitive. Similarly, the writers covertly draw the mood of their readers to the loss or aphaeresis of African communalism. They suggest that the mode of economic production in Africa needs to change in order to end the misery of the oppressed population. To realise this, they advocate a return to communal living, and this communal consciousness is a parallel of Ngugi's Ujaama socialist philosophy. 


\section{References}

Adebayo, Aduke. 1985. "Heroes and Anti-heroes in the Novels of Sembene Ousmane." In Modern Essays on African Literature: Studies in the African Novel, edited by Samuel Omo Asein and Albert Olu Ashaolu, 57-71. Ibadan: Ibadan University Press.

Alofun, Olufolake O. 2014. "African Socialism: a Critique." IOSR Journal of Humanities and Social Science (IOSR-JHSS) 19 (8): 69-71.

Barry, Peter. 1995. Beginning Theory: An Introduction to Literary and Cultural Theory. Manchester: Manchester University Press.

Césaire, Aimé. 1972. Discourse on Colonialism (Discours sur le colonialism). New York and London: Monthly Review Press.

Dada, Pius Olusegun. 1985. “The Tradition of the African Novel." In Modern Essays on African Literature: Studies in the African Novel, edited by Samuel Omo Asein and Albert Olu Ashaolu, 27-36. Ibadan: Ibadan University Press.

Farrow, Steve. 1999. The Really Useful Science Book: A Framework of Knowledge for Primary Teachers. London: Routledge.

Guralnik, David B. 1979. Webster's New World Dictionary of the American Language. Cleveland: William Collins Publishers.

Ikiddeh, Ime. 1985. "Ideology and Revolutionary Action in the Contemporary African Novel." In Modern Essays on African Literature: Studies in the African Novel, edited by Samuel Omo Asein and Albert Olu Ashaolu, 37-56. Ibadan: Ibadan University Press.

Landreth, Harry, and Colander, David C. 2002. History of Economic Thought. Boston: Houghton Mifflin.

Landy, Marsha. 1982. "Politics and Style in Black Girl." Jump Cut 27 (July): 23-25. https://www.ejumpcut. org/archive/onlinessays/JC27folder/BlackGirlLandy.html

Mbiti, John. 1970. African Religions and Philosophies. New York: Doubleday and Company.

Miller, Ruth, and Greenberg, Robert A. 1981. Poetry: an Introduction. London: Macmillan.

Ngugi, wa Thiong'o. 2002. Devil on the Cross. Ibadan: Heinemann Educational Books.

—. 2007. "Writers in Politics: the Power of Words and the Words of Power. In African Literature: An Anthology of Criticism and Theory, edited by Tejumola Olaniyan and Ato Quayson, 476-83. London: Blackwell Publishing.

Ogundokun, Sikiru Adeyemi. 2014. "Revolutionary Aesthetics in Sembene Ousmane's God's Bits of Wood." Global Journal of Arts Humanities and Sciences 2 (4): 72-79.

Olaniyan, Tejumola, and Ato Quayson, eds. 2007. African Literature: an Anthology of Criticism and Theory. London: Blackwell Publishing.

Onoge, Omafume F. 2007. “Towards a Marxist Sociology of African Literature.” In African Literature: An Anthology of Criticism and Theory, edited by Tejumola Olaniyan and Ato Quayson, 463-75. London: Blackwell Publishing.

Ousmane, Sembene. 1960. God's Bits of Wood. Oxford: Heinemann.

Rankin, Keith. 2011. "Mercantilist Reasoning in Economic Policy Making." Conference of the New Zealand Association of Economists, 29th June-1st July, Wellington, New Zealand.

Steil, Benn. 1994. "'Social Correctness' is the New Protectionism." Foreign Affairs 73 (January/ February):14-20.

Tyson, Lois. 1999. Critical Theory Today: A User-friendly Guide. New York: Garland Publishers, Inc. 